\title{
Constraints on food choices of women in the UK with lower educational attainment
}

\author{
M Barker ${ }^{1, *}$, WT Lawrence ${ }^{1}$, TC Skinner ${ }^{2}$, CO Haslam³ ${ }^{3}$ SM Robinson ${ }^{1}$, HM Inskip ${ }^{1}$, \\ BM Margetts $^{1}$, AA Jackson ${ }^{1}$, DJP Barker ${ }^{1}, \mathrm{C} \mathrm{Cooper}^{1}$ and the Food Choice Group, \\ University of Southampton \\ ${ }^{1}$ Food Choice Group, MRC Epidemiology Resource Centre, University of Southampton, Southampton General \\ Hospital, Southampton SO 16 6YD, UK: ${ }^{2}$ School of Psychology, University of Wollongong, Northfields Avenue, \\ Wollongong, New South Wales 2500, Australia: ${ }^{3}$ Department of Human Sciences, Loughborough University, \\ Loughborough, Leicestershire LE 11 3TU, UK
}

Submitted 28 June 2007: Accepted 14 December 2007: First published online 26 February 2008

\begin{abstract}
Objective: Women of lower educational attainment have less balanced and varied diets than women of higher educational attainment. The diets of women are vital to the long-term health of their offspring. The present study aimed to identify factors that influence the food choices of women with lower educational attainment and how women could be helped to improve those choices.

Design: We conducted eight focus group discussions with women of lower educational attainment to identify these factors. We contrasted the results of these discussions with those from three focus group discussions with women of higher educational attainment.

Setting: Southampton, UK.

Subjects: Forty-two white Caucasian women of lower educational attainment and fourteen of higher educational attainment aged 18 to 44 years.

Results: The dominant theme in discussions with women of lower educational attainment was their sense that they lacked control over food choices for themselves and their families. Partners and children exerted a high degree of control over which foods were bought and prepared. Women's perceptions of the cost of healthy food, the need to avoid waste, being trapped at home surrounded by opportunities to snack, and having limited skill and experience with food, all contributed to their sense they lacked control over their own and their family's food choices.

Conclusions: An intervention to improve the food choices of women with lower educational attainment needs to increase their sense of control over their diet and the foods they buy. This might include increasing their skills in food preparation.
\end{abstract}

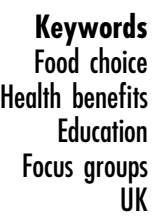

Keywords

Education Focus groups
Studies from across Europe have identified a relationship between educational attainment and diet. Education level was the most important social variable in explaining differences in vegetable and fat intake in a random sample of Danish men and women ${ }^{(1)}$, and having no qualifications was a significant predictor of low healthy eating scores in 7434 men and women in the Scottish Health Survey ${ }^{(2)}$. In a group of 6125 women who took part in the Southampton Women's Survey, it was found that women who leave school with few or no qualifications eat a less balanced or 'prudent' diet than women with qualifications ${ }^{(3)}$. A 'prudent' diet in this survey was characterised by high intakes of fruit and vegetables, wholemeal bread, rice, pasta, yoghurt and breakfast cereals. An 'imprudent' diet was characterised by high intakes of chips and roast potatoes, sugar, white bread, red and processed meats, full-fat dairy products, crisps, sweets, tinned vegetables, cakes and biscuits. More than half of the women who left school with no qualifications were in the lowest quarter of the 'prudent' diet score. This proportion fell progressively with increasing qualifications, so that only $3 \%$ of women with university degrees had scores in the lowest quarter. This relationship was not explained by social class.

Women's diets are important not only for their own health but also for that of their children. Recent studies across Europe and in the USA provide consistent evidence that CHD, stroke, type II diabetes and osteoporosis originate through faltering growth of babies in the womb and after birth ${ }^{(4)}$. A woman's ability to nourish her baby 
and thereby protect its growth and development depends on her diet before and during pregnancy. Campbell et al. established that women who ate a diet unbalanced in the proportion of protein to carbohydrate had offspring with higher blood pressures as adults ${ }^{(5)}$. Men and women whose mothers were pregnant with them during the Dutch wartime famine tended to be insulinresistant in later life ${ }^{(6)}$. It follows that improving the diets of young women would improve the health of the next generation.

What is it about women of lower educational attainment that leads them to choose unbalanced and unvaried diets? It is unlikely in the UK that education influences dietary choices through teaching about food and nutrition in schools and colleges. Little is taught formally here about food after the age of 16 years. It is more likely that educational attainment is a marker for differences in lifestyles and in the priority given to diet. Although lower educational attainment has been associated with poorer health $^{(7)}$ and with poorer diet quality ${ }^{(1,8)}$, almost nothing is known about exactly how educational attainment acts on food choices. Because young women's diets are important in determining the health and well-being of generations to come, it is important to understand what underlies the relationship between educational attainment and diet. The purpose of the present study was to identify lifestyle and other factors that influenced the food choices of women of lower educational attainment and how these women could best be helped to improve their food choices.

\section{Methods and procedures}

\section{Participants}

Focus group discussions were held in the city of Southampton, UK between July 2004 and July 2006. Eleven focus group discussions were held in total: eight of them with women of lower educational attainment and three with women of higher educational attainment. All the women were white Caucasian. Numbers of women in each focus group ranged from three to eight, and were in line with Krueger and Casey's recommendation for the number of participants needed ${ }^{(9)}$. Lower educational attainment was defined as either leaving full-time education at 16 years with no qualifications or as having attained GCSE (school leavers) level qualifications. Higher educational attainment was defined as having a university degree. Southampton is a city on the south coast of England. It has a population of approximately 250000 and a pattern of deprivation that broadly reflects that of the UK as a whole. Four of the groups of women with lower educational attainment were recruited from women attending Southampton's Sure Start programme, which provides health and social services to families with children below 5 years of age. Women were purposefully recruited from among Sure Start clientele because Sure Start centres in Southampton are situated in areas of high deprivation and would therefore serve a population with generally low socio-economic status and hence low educational attainment. The other four discussions with women of lower educational attainment were held in a local church hall in a deprived area with women who were attending a support group financed by Sure Start for women with young children. Women in two of the higher educational attainment groups were recruited from those who had previously taken part in the Southampton Women's Survey ${ }^{(10)}$. The remaining group was a purposive sample of women of higher educational attainment selected because they all had young children. Most of these women had professional qualifications and lived in more affluent parts of the city. The number of discussion groups was limited by the convention that no more discussions need to be undertaken when no new information emerges ${ }^{(9)}$.

\section{Materials}

Information on age, number of children living at home and level of education attained was recorded for each woman. Discussions were structured around a discussion guide, based on themes derived from a review of the literature and discussions with nutritionists, epidemiologists and social scientists in the field. The discussion guide was piloted in a convenience sample of women of mixed educational attainment recruited from the researchers' work place, to check coherence and timing. The discussion guide covered five broad areas of inquiry.

1. Social: the influence of family and friends.

2. Environmental: external factors that might constrain food choices such as access to shops, money and time.

3. Historical: childhood eating experiences, learning to cook and changes in eating habits at each life stage.

4. Psychological: themes more likely to be implicit in discussions, such as health beliefs, self-esteem and perceptions of control.

5. Intervention: the women's ideas about what they would like to change about their food choices and how they might be helped to do that.

All participants were provided with an information sheet explaining the reasons for the study and the nature of the discussion. Discussions lasted approximately $2 \mathrm{~h}$ and the women's consent to take part was obtained before discussions began. The study had ethical approval from the Southampton and South West Hampshire Local Research Ethics Committee.

\section{Procedure}

A moderator (W.T.L.) led the discussion and an observer (M.B.) monitored and made notes. To break the ice and begin generating discussion, participants were shown 
photographs of the interiors of fridges belonging to women in the Southampton Women's Survey ${ }^{(11)}$. The observer fed-back to the moderator half-way through each session to ensure all areas of the discussion guide were covered. Discussions were audio-taped and transcribed verbatim. These transcripts were the basis of the analysis.

\section{Analysis}

Analysis was driven by the study's central purpose, which was to understand why women of lower educational attainment appear to make poorer food choices than women of higher educational attainment. Responses of women of lower educational attainment were compared with those of women of higher educational attainment, and the similarities and differences noted.

Transcripts were read and re-read. Comments from participants were coded into a coding frame based on the themes of the discussion guide ${ }^{(12)}$ (Table 1). The two researchers analysed half the transcripts each, using constant comparative methods and making suggestions for amendments or elaboration, collapsing or expanding categories. Sub-sections of four transcripts were coded by both researchers (M.B. and W.T.L.) to assess inter-rater reliability of coding. A $96 \%$ level of agreement was reached. Data under each theme were summarised and verbatim quotes used to illustrate the theme.

\section{Findings}

Forty-two women of lower educational attainment and fourteen women of higher educational attainment took part in the discussions. They were aged between 18 and 44 years. All of the women of lower educational attainment and five of the women of higher educational attainment were living with children. Results of the discussions are presented as they bear on the first four themes of our discussion guide. Women's suggestions for ways in which they could be helped to change their diets are included in our description of these four themes.

\section{Social influences}

\section{Influence of partners and children}

Partners of women in both groups were influential in food choice decisions for the household. However, partners of women of lower educational attainment were more likely to be making food choices for themselves and their families that the women were not happy with. In the following, which comes from a discussion with women of lower educational attainment, the partner's insistence on having crisps in the house meant that they were accessible to the woman, which was not supportive of her attempts to lose weight.
Moderator: Would you shop differently now you're on a diet?

Woman: Not really, I still buy um crisps and that lot, 'cos my partner eats twenty-four in one day. So I still buy those.

Moderator: Packets?

Woman: Yeah.

Other woman: Ooh wow, that's gross!

Other woman: He will go through a big bag, will he?

Woman: A multi pack - that's his in one night.

In households of some women of lower educational attainment, it was that clear children exercised a high degree of control over food choices for the family, sometimes with consequences for the household food budget and often with the result that this limited the variety of foods they would eat.

But my kids, they won't eat normal spaghetti. If I went and bought normal spaghetti, then if they saw like Scooby Doo [spaghetti] or something like that, they'd eat that. I know that they'd eat that. So if they say 'oh Mum can we have this', then I'll get it because I know that they'll eat it, but they wouldn't eat normal spaghetti. I think when you pay like double the price for half a tin ... yeah just for a little tin, but I know that they'll eat that so I'd rather give it to them.

In general, women of lower educational attainment felt their partners and children saw no reason to change the way they ate, and would not support attempts to improve the family's diet.

There was far less evidence in discussion with women of higher educational attainment that children were making their own choices about what to eat, and no evidence to suggest that children's choices were affecting the eating habits of the whole household. Partners of women of higher educational attainment were more often described as involved in shopping and cooking decisions, and tended to be more supportive of women's attempts to eat a balanced and varied diet. In the following, the woman's partner was more involved than most women's partners in cooking for the family, but the quote is indicative of an attitude to eating more prevalent in households of women of higher educational attainment:

This weekend I said 'oh I think we could do something - bacon or lettuce for lunch' and I'd got some hard boiled eggs I'd forgotten to use. He did a really nice salad with ... cous cous, broad beans and coriander, and then he did crispy, crispy bacon, eggs and cos lettuce or something, and it was very nice, very delicious and I thought 'what more could you ask for?'

There was no evidence that partners of women with lower educational attainment were involved in food planning and preparation in this way. 
Table 1 Coding frame used to analyse the discussion transcripts

\begin{tabular}{|c|c|c|}
\hline Code name & Description & Exclusions \\
\hline $\begin{array}{l}\text { Historical - } \\
\text { childhood }\end{array}$ & $\begin{array}{l}\text { Experiences of shopping, cooking and } \\
\text { family mealtimes; parental attitudes } \\
\text { and behaviour }\end{array}$ & $\begin{array}{l}\text { Any mention of dietary } \\
\text { changes and food } \\
\text { choices NOT } \\
\text { associated with life } \\
\text { stages }\end{array}$ \\
\hline $\begin{array}{l}\text { Historical - } \\
\quad \text { single adult }\end{array}$ & $\begin{array}{l}\text { Life stage transition - changes due to } \\
\text { experience of living alone }\end{array}$ & \\
\hline $\begin{array}{l}\text { Historical - } \\
\text { marriage/ } \\
\text { partner }\end{array}$ & $\begin{array}{l}\text { Life stage transition - changes due to } \\
\text { experiences once in a relationship }\end{array}$ & \\
\hline $\begin{array}{l}\text { Historical - } \\
\text { children }\end{array}$ & $\begin{array}{l}\text { Life stage transition - changes due to } \\
\text { experiences during pregnancy and } \\
\text { since having children }\end{array}$ & \\
\hline Social - peers & $\begin{array}{l}\text { Peer influences on woman or family, } \\
\text { comparison of eating habits with } \\
\text { friends/colleagues/social context }\end{array}$ & \\
\hline Social - family & $\begin{array}{l}\text { Comparison of eating habits with } \\
\text { relatives, incl. influence of partner and/ } \\
\text { or children }\end{array}$ & \\
\hline $\begin{array}{l}\text { Social - } \\
\text { company }\end{array}$ & $\begin{array}{l}\text { Context of own eating - who's around, } \\
\text { woman's mealtime experiences }\end{array}$ & \\
\hline $\begin{array}{l}\text { Environment - } \\
\text { cost }\end{array}$ & $\begin{array}{l}\text { Cost of food, consideration of budget/ } \\
\text { value foods }\end{array}$ & $\begin{array}{l}\text { NOT suggestions for } \\
\text { ways of improving } \\
\text { diet }\end{array}$ \\
\hline $\begin{array}{l}\text { Environment - } \\
\text { waste }\end{array}$ & Worrying about wasting food & \\
\hline $\begin{array}{l}\text { Environment - } \\
\text { shopping }\end{array}$ & Shopping practices and access to shops & \\
\hline $\begin{array}{l}\text { Environment - } \\
\text { time }\end{array}$ & Time pressures and making time & \\
\hline $\begin{array}{l}\text { Environment - } \\
\text { home }\end{array}$ & $\begin{array}{l}\text { The home environment and associated } \\
\text { problems, incl. boredom }\end{array}$ & NOT emotional eating \\
\hline $\begin{array}{l}\text { Environment - } \\
\text { work }\end{array}$ & $\begin{array}{l}\text { The effect of the work environment on } \\
\text { food choice/eating habits }\end{array}$ & \\
\hline $\begin{array}{l}\text { Environment - } \\
\text { eating out }\end{array}$ & $\begin{array}{l}\text { Any reference to eating out and } \\
\text { takeaways }\end{array}$ & \\
\hline $\begin{array}{l}\text { Psychological - } \\
\text { control }\end{array}$ & $\begin{array}{l}\text { Who's controlling the food choices of } \\
\text { family? Family demands and refusals/ } \\
\text { fussy eaters }\end{array}$ & \\
\hline $\begin{array}{l}\text { Psychological - } \\
\text { restraint }\end{array}$ & $\begin{array}{l}\text { Own self-control (or lack of control) over } \\
\text { food/eating opportunities on own } \\
\text { eating behaviour; dieting or } \\
\text { dysfunctional eating habits }\end{array}$ & $\begin{array}{l}\text { NOT due to presence/ } \\
\text { absence of others at } \\
\text { mealtime }\end{array}$ \\
\hline $\begin{array}{l}\text { Psychological - } \\
\text { health now }\end{array}$ & $\begin{array}{l}\text { Health value - consideration of own or } \\
\text { other's immediate health; current } \\
\text { health issues. Explicit mention of } \\
\text { current well-being/health }\end{array}$ & $\begin{array}{l}\text { NOT long-term health } \\
\text { considerations }\end{array}$ \\
\hline $\begin{array}{l}\text { Psychological - } \\
\text { health future }\end{array}$ & $\begin{array}{l}\text { Health value - consideration of own or } \\
\text { other's future health; good/bad food } \\
\text { distinctions }\end{array}$ & $\begin{array}{l}\text { NOT short-term health } \\
\text { considerations }\end{array}$ \\
\hline $\begin{array}{l}\text { Psychological - } \\
\text { self-esteem }\end{array}$ & $\begin{array}{l}\text { Low self-esteem/self-worth, always } \\
\text { putting others first and not taking time } \\
\text { for self }\end{array}$ & \\
\hline $\begin{array}{l}\text { Psychological - } \\
\text { food } \\
\text { involvement }\end{array}$ & $\begin{array}{l}\text { Interest/engagement with food, e.g. } \\
\text { reads articles or labels, watches TV } \\
\text { programmes, nutrients and dietary } \\
\text { advice, planning, preparing and } \\
\text { cooking; awareness of changing } \\
\text { preferences/tastes over time }\end{array}$ & \\
\hline $\begin{array}{l}\text { Psychological - } \\
\text { emotion }\end{array}$ & $\begin{array}{l}\text { Eating associated with boredom, mood, } \\
\text { pleasure, reward }\end{array}$ & \\
\hline $\begin{array}{l}\text { Psychological - } \\
\text { confidence }\end{array}$ & $\begin{array}{l}\text { Confidence or lack of it regarding cooking } \\
\text { and associated activities. Evidence of } \\
\text { low or high self-efficacy }\end{array}$ & \\
\hline $\begin{array}{l}\text { Intervention - } \\
\text { education }\end{array}$ & $\begin{array}{l}\text { Wish to learn more about foods, cooking, } \\
\text { incl. demonstrations }\end{array}$ & \\
\hline
\end{tabular}
'Very strict meals and if we didn't like what was cooked then we would have to go to the next meal before we had anything else.'

'When I lived on my own ...'

'I used to be really small and then I met my husband and that was it, I got fat.'

'Before we had the children ...'

'A lot of people can't even cook.'

'My sister has the same sort of tastes as I have, but my mum hasn't.'

'If my kids go away for the weekend, I don't cook a whole big dinner for myself.'

'So to buy like proper cod fish fingers and things like that are more expensive than buying 20 .'

'Um, fresh goes off, probably like everyone in the family doesn't really eat it.'

'Well I don't drive; that why I do mine daily.'

'Quick and easy, if you've got in late or kids are tired.'

"Take the time and do fruit meringue."

"Evenings and weekends. Weekends are the worst.'

'She works, she you know she's not at home, so her eating habits have totally changed.'

'Take the kids down to McDonalds or something.'

'My husband tells me what to cook and I cook it.'

'I can go all day. I've gone a couple of days without food before when l've, 'cos l've just not thought about it.'

'My body hasn't had anything for hours when I've been asleep, um so I just kick start it, it gives me energy as well.'

'Oil and stuff's not good for you. It hardens and sticks to all your arteries, it's disgusting.'

'So most of the time, I make them dinner and then I end up eating rubbish later on.'

'It's more fun to go and cook it than it is to go out and buy the biscuits or cakes.'

'No, I'm not interested in food ... I need to be in the mood to eat.'

'When I get upset, if I'm sat in doors and I'm depressed ... I'll sit there and eat loads.'

'And I would think, OK I can do that, yeah.'

'I'm just scared it's going to go wrong I think.'

'It's a lot easier and simpler to have someone to show you and then you taste it after and then ... you can actually see what it looks like.' 
Table 1 Continued

\begin{tabular}{|c|c|c|c|}
\hline Code name & Description & Exclusions & Examples \\
\hline $\begin{array}{l}\text { Intervention - } \\
\text { activities }\end{array}$ & $\begin{array}{l}\text { Wish to engage in activities outside the } \\
\text { home, incl. exercise programmes }\end{array}$ & & $\begin{array}{l}\text { 'Be a bit more active and then if I was more } \\
\text { active I wouldn't be sat there thinking } \\
\text { about food and eating food.' }\end{array}$ \\
\hline $\begin{array}{l}\text { Intervention - } \\
\text { cost }\end{array}$ & $\begin{array}{l}\text { Healthy food to be more affordable, food } \\
\text { vouchers, etc. }\end{array}$ & & $\begin{array}{l}\text { 'In an ideal world l'd be able to go round } \\
\text { Tesco's and chuck it in the trolley and } \\
\text { think I don't care when I get to that till how } \\
\text { much it's going to cost, but I do.' }\end{array}$ \\
\hline $\begin{array}{l}\text { Intervention - } \\
\text { other }\end{array}$ & $\begin{array}{l}\text { Any other suggestions for helping } \\
\text { change }\end{array}$ & & 'Other things delivered, anything delivered.' \\
\hline
\end{tabular}

\section{Environmental influences}

\section{Cost and waste}

It was a common perception among the groups of women of lower educational attainment that 'healthy' food was more expensive. Some felt they could not afford it.

A lot of the time [it's] money. 'Cos when, when you go from shopping like with junk food and then to the healthy food, it can be a big change in ... I mean I'm now spending nearly £100, well most weeks 100 every week, whereas before I was spending forty or fifty quid. And now I'm spending a hundred, so it is the money that's a big thing.

For some, this was because shopping healthily meant upgrading the quality of the processed food products they bought:

Yeah, you can get ten normal, well ten rubbish, economy fish fingers for 26p and things like that. And then when you go to the cod ones you are paying $£ 2$ or $£ 3$, and it is very dear.

For others, it was the relative cost of fruit and vegetables at the supermarket:

Fruit and veg is expensive. It's a shame they can't make that cheaper, rather than make all the crap food special offers. There's always buy-one-getone-free isn't there on a packet of chicken nuggets or something.

On a limited budget, women did not want to risk wasting food, which meant some of them bought little fresh food. Fresh fruit and vegetables were seen to be particularly wasteful because they were very likely not to be eaten and 'went off' very quickly:

But when it's only me and the two children ... they don't really like vegetables. I'm lucky if I can get in the odd carrot, or couple of peas or sweetcorn, so it's all gonna go off. So I just buy a bag [of frozen vegetables].

This need to balance cost and waste was a recurrent theme in our discussions with women of lower educa- tional attainment. They felt it dictated what foods they bought. They could not afford to have food tried, not liked and thrown away, so they tended to buy what they knew they, their children and partners liked and would eat:

Woman 1: I think that's why you stick to the stuff that you like because you know you like it and you know if you're going to buy it, you're not going to waste it.

Woman 2: It's the same with the children as well, you know they'll eat it.

Woman 1: Yeah, yeah, I stick to what they like, you know, 'cos I know that it's not gonna get wasted.

Again, these experiences were in sharp contrast to those of women with higher educational attainment:

I don't buy economy anything, you know and I'll only buy sort of like $100 \%$ beef products. I'll only buy the, sort of, best chicken. I'll only buy meat from this country.

Discussions with these women were focused on the importance of providing their families with fresh meat and vegetables. There was no mention of waste as an issue, and cost was only discussed in relation to being able to afford top-quality or organic produce.

[Organic] it's a better taste. I mean I think that I buy the things that I think taste good. Like I don't buy all organic vegetables but I buy the ones that taste better. ... I do feel really bad about spending what we spend.

\section{Shopping}

There was no evidence that women of lower educational attainment had difficulty getting to the supermarket to do their shopping, despite the fact that fewer of them than women of higher educational attainment appeared to have cars. However, women of lower educational attainment did talk more about the difficulties of having to take their children shopping with them.

I don't drive, I have to rely on another person to take me shopping and ... it's always a hectic time. 
I think when you've got ... I've got two kids and it's 'I want this, I want that' and I'm like 'MY GOD, we're trying to shop alright!'

These groups of women also described the difficulty of shopping locally with small children. Buying and transporting fruit and vegetables was a particular issue, because they are heavy and bulky. The women mentioned having overloaded and broken pushchairs trying to carry their fruit and vegetables home. For this reason, they suggested deliveries of fresh fruit and vegetables might make it easier to serve them to their families. They also requested that these deliveries be subsidised. If fruit and vegetables were cheaper it would make it easier for them to experiment. The risk of waste would not be so critical.

\section{Access to food}

Women of lower educational attainment were more likely to be at home with small children than women of higher educational attainment. This difference in lifestyle was critical to the way women ate. Women of lower educational attainment who were at home described feeling, bored, trapped and having constant opportunities to eat. They were tempted to snack.

I eat a lot on a Monday night 'cos my husband goes out. You know, I'm at home on my own and it's just so boring.

Some women compared their current experience with the way things had been while they were going out to work:

Because I'm at home, you are always by the fridge. There's more opportunities to snack. Then when you're at work you're not even thinking about it 'cos you're doing other stuff ... whereas when you're at home you're like 'Oh, what are we going to have for lunch? What are we going to have for dinner?' ... When you're out working you're thinking, you know, 'What am I doing tonight? Where am I going tonight?' ... You're thinking about different kinds of things so you're not thinking about food as much as I think about food now. Food is something I think about a lot.

Women of higher educational attainment, more of whom were working, recognised they were removed from the temptations of food at home, and tended to control their opportunities to eat at work.

I've got lots of food and things and there's a snack machine just down the corridor, so if I'm sitting there thinking 'oh bar of chocolate', I think 'right I'll eat the apple first and then give it half an hour and see if I'm still hungry', so then I try to force myself to eat the fruit rather than the chocolate snack.

\section{Historical influences}

Skills and experience

Although there were wide variations across the group, there were women of lower educational attainment who had not been taught or shown how to cook.

You know ... I was never allowed in the kitchen as a child ...

I taught myself how to cook. Recipes just off the back of a packet ...

There were also women who had experienced a limited range of foods when they were growing up.

We had a set meal every day of the week, so basically quite boring ... only liked Fridays, it's pie \& chips day! The rest of it was like roast dinner, cold meat \& chips, the roast dinner that was left over ... quite boring.

These women felt they did not know how to prepare or enjoy a wide variety of foods. This meant they were unlikely to want to serve new or different foods to their families. The following quote is from a woman who professed to hate vegetables and was taken to task by her mother for not serving them to her children:

She said 'just because you don't like it, you've still got to buy it because they might like it'.

It was more usual for women of higher educational attainment to have been actively shown how to cook and to have experienced a wider variety of foods:

I don't think I would have been allowed to have left home unless I knew how to cook a roast dinner.

I remember my dad going through a phase where he thought we should like look at vegetarian and vegan type stuff ... we still ate meat and stuff but we also had like seaweed. My mum eats all sorts of food ... I've had served up to me as a child, I've had brains, I've had heart ... haven't had tripe ... but liver and kidney quite regularly.

Women of lower educational attainment who had limited skill and experience with food suggested that personalised cooking and shopping instruction, preferably in their own homes or in the homes of friends, would be helpful.

\section{Psychological influences}

\section{Control}

The dominant psychological theme underlying our discussions with women of lower educational attainment was their perceived lack of control over food choices for the household. Discussions suggested that the combination of social, environmental and historical influences described above served to undermine their sense of control. Sometimes they expressed this explicitly. 
Woman: I get told what to cook.

Moderator: So how does that work?

Woman: My husband tells me what to cook and I cook it!

In other conversations, it was implicit:

Moderator: So what do you do then if they're throwing their food away? Do you worry that they're not eating?

Woman: No. I just give them something else something they do like.

Other women described having tried to control the family's food choices, but had given up. In the following example, the woman was no longer trying to exercise control because she could see no benefit to anyone in doing so.

I tend to have all freezer foods. I have a problem with my partner and my son, they don't eat a lot of fruit and veg. Like, I cook meals and I just get fed up of doing it 'cos they won't eat it, so I don't bother half the time, which is naughty, but ...

This was not how they wanted the food choices for their households to be made. This same woman went on to say:

I've tried so many times but it's just pointless. I get stressed very easily, and I don't get a lot of support at home for it ... so I tend not to bother.

The major concern of women in this situation was that they felt their families were eating a poorer-quality diet than they should do. In the previous example, 'freezer foods' were the processed meat, fish and potato products that the woman's family would eat willingly. She was clearly unhappy that she was not cooking meals containing fruit and vegetables, the implication being that she believed these would be better for her family than 'freezer foods'. This was likely to be affecting the quality of her diet as well as her family's. If she was not cooking fruit and vegetables for her family, she was unlikely to be eating them herself. In the following example, a woman explains how her daughter's refusal to eat a variety of foods restricted her own diet.

I would eat anything or cook anything, but then I'd have to do two separate dinners all the time. I do it, but it's really frustrating. The only thing what we find that she [her daughter] likes are cold kebabs and spaghetti bolognaise. That's the only thing.

The contrast with discussions from groups with women of higher educational attainment was marked. These women were much more likely to feel in control of food choice decisions for the household, as the following exchange illustrates:

Woman: He [her partner] doesn't ever want to be given a choice about things because he says 'I'm making decisions all day. I want you to choose what
I'm going to have and I want you to put it in front of me and let me eat it' and not to have anything to do with it, so yes. He can't cook at all.

Moderator: Does he eat most things?

Woman: Yes, he's not particularly fussy ... in fact

I can't even think of anything that he wouldn't eat.

Where there was any dissention in the family, women of higher educational attainment described a range of strategies for overcoming the reluctance of family members to eat particular foods.

I need to start pushing rice again really because he [her son] likes rice but she [her daughter] doesn't. I just kind of think I'm going to have to start gradually starting reintroducing it.

\section{Discussion}

The dominant theme that emerged from focus group discussions with women of lower educational attainment was their sense that they lacked control over food choices for themselves and their families. Partners and children gave them little support for making healthy food choices, and exerted a high degree of control over foods bought and prepared for the family. Environmental impediments, such as their perceptions of the cost of healthy food, the need to avoid waste and being trapped at home surrounded by opportunities to snack, constrained these women's freedom to make healthy food choices. Having limited skill and experience with food further undermined the ability of this group of women to feed their families in the way they felt they should. All these factors contributed to women's loss of control over their own and their family's food choices. Discussions with women of higher educational attainment made it clear that they felt far more in control, received more social support, were less constrained by the environment in which they lived and tended to have a greater store of skills and experience with food than women of lower educational attainment.

These and other data ${ }^{(13)}$ suggest that family food choices are arrived at through a process of negotiation between the women, who is usually providing the food, and the partner and children as consumers. Because of this, family food choices have been used to illustrate the way gender issues are manifested in our society ${ }^{(14)}$. Cooking is 'women's work' but decisions about what to cook are heavily influenced by husbands and partners ${ }^{(15)}$. This was evident in our discussions with women in the way they described who controlled the food choice decisions in their households.

A general sense of control is important for healthy psychological functioning, and has been repeatedly shown to predict physical and mental well-being ${ }^{(16)}$. Control over food choices was not a theme we had 
anticipated when devising our question route, and we were surprised at the extent to which it dominated our conversations with women of both levels of educational attainment. Skinner describes a sense of control as the product of an interdependent relationship between person, behaviour and outcome ${ }^{(17)}$. The relationship between person and behaviour is characterised by beliefs in one's own ability to perform that behaviour. In the case of women in our discussion groups, this would be their belief in their ability to prepare and serve the meals they would like to, based on their skill and experience. The relationship between person and outcome in our data is based on the women's belief that there is a link between diet and health that they can control. Behaviour and outcome are linked by the women's belief that by cooking and serving healthy meals, they can improve their family's health. This last connection is dependent on the women possessing strategies that ensure their families eat the healthy meals. Breaks in any one of these three links will result in erosion of women's sense of control over the whole arena of food choices for the family.

Though our data may give rise to this hypothesis, the study as it stands cannot test it. It is a relatively small study, and the participants' views are not necessarily representative of those of the whole population of interest. In addition, the study only enables us to discuss differences at a group level rather than between individuals. A larger study recording views and experiences of individuals would be needed to confirm findings from the focus group discussions. However, the methodology adopted for running the discussions and analysing the transcripts gives us confidence that we are fairly representing the views of our participants. One major difference between our women of higher and lower educational attainment was that only two-thirds of women of higher educational attainment had children, whereas all our women of lower educational attainment had children. This might suggest that we were not comparing like with like when examining the experiences of these two groups of women. However, our study was designed to reflect differences in their lifestyles: one major difference that appears to affect food choices is whether or not they have children, and women of lower educational attainment in Southampton are more likely to have children at the age they were recruited for the Southampton Women's Survey than women of higher educational attainment (SR Crozier, personal communication). Our data reveal that those women of higher educational attainment who did have children faced some of the same issues in feeding them as women of lower educational attainment, but tended to respond differently.

The present paper is intended as a brief review of the findings of our focus group discussions that might interest a public health nutrition audience. We are aware that in our review we touch on a host of issues it would be useful to explore at greater length. With this in mind, we have prepared a longer paper dealing with the psychological issues underlying the difficulties some of our participants had with feeding themselves and their families (W Lawrence, TC Skinner, C Haslam, S Robinson, H Inskip, D Barker, C Cooper, A Jackson, M Barker \& the Food Choice Group, University of Southampton. 'I ain't fat, you are. I don't need to diet': why women of low educational attainment struggle to make healthier food choices. Manuscript in preparation).

Our study contributes to the small body of qualitative data about the food choices of women ${ }^{(18,19)}$, an issue of great importance for the health of the next generation. There is a hierarchy of needs with regard to food choices: first, to eat food, and second, to eat food that confers special benefit. Our data show that for women of lower educational attainment providing food is a high priority, but that the special benefit they prioritise is to satisfy the wishes of their families, rather than confer longer-term health benefits to them or themselves. Experiencing a number of pressures, they prioritise an immediate achievement over a more distant achievement. We speculate that this may be the key to understanding why women of lower educational attainment have less balanced and varied diets than women of higher educational attainment.

The present findings implicate the role of social agency, individual choice, social structures and policy in determining the food choices of these women. All of these will have to be addressed in any future intervention to improve food choices. Equally, the data show that any intervention to improve the diet of women of lower educational attainment would have simultaneously to raise the priority they give to the longer-term health benefits of food, and ease the pressures on them by equipping them with practical skills to make it easier for them to access good quality food, provide such food for their families and persuade them to eat it.

\section{Acknowledgements}

There are no conflicts of interest. This study was funded by Danone Institute International. M.B. and W.T.L. collected the data, conducted the analysis and drafted the article. T.C.S. helped design the study and analyse the data. C.O.H., S.M.R., H.M.I., B.M.M., A.A.J., D.J.P.B. and C.C. all contributed to the data analysis and interpretation, and revised successive drafts of the manuscript.

Acknowledgements: Thanks are due to the women who gave up their time to speak to us, to the staff at Sure Start centres in Southampton and Southampton Voluntary Services, and to Professor Susan Michie for her comments on an earlier draft of this paper.

\section{References}

1. Groth MV, Fagt S \& Brøndsted L (2001) Social determinants of dietary habits in Denmark. Eur J Clin Nutr 55, 959-966. 
2. Shelton NJ (2005) What not to eat: inequalities in healthy eating behaviour, evidence from the 1998 Scottish Health Survey. J Public Health 27, 36-44.

3. Robinson SM, Crozier SR, Borland SE, Hammond J, Barker DJP \& Inskip HM (2004) Impact of educational attainment on the quality of young women's diets. Eur J Clin Nutr 58, 1174-1180.

4. Barker DJP (2003) The Best Start in Life, 1st ed. London: Random House.

5. Campbell DM, Hall MH, Barker DJP, Cross J, Shiell AW \& Godfrey KM (1996) Diet in pregnancy and the offspring's blood pressure 40 years later. Br J Obstet Gynaecol 103, 273-280.

6. Roseboom TJ, van der Meulen JHP, Ravelli AC, Osmond C \& Barker DJP (2001) Effects of prenatal exposure to the Dutch famine on adult disease in later life: an overview. Twin Res 4, 293-298.

7. Matthews KA, Kelsey SF, Meilahn EN, Kuller LH \& Wing RR (1989) Educational attainment and behavioural and biologic risk factors for coronary heart disease in middle-aged women. Am J Epidemiol 129, 1132-1144.

8. Lawlor DA, Batty GD, Morton SMB, Clark H, Macintyre S \& Leon DA (2005) Childhood socioeconomic position, educational attainment, and adult cardiovascular risk factors: the Aberdeen Children of the 1950s cohort study. Am J Public Health 95, 1245-1251.

9. Krueger RA \& Casey MA (2000) Focus Groups: A Practical Guide for Applied Research, 3rd ed. Thousand Oaks, CA: Sage Publications, Inc.

10. Inskip H, Godfrey KM, Robinson SM, Law CM, Barker DJP \& Cooper C, SWS Study (2006) Cohort profile:
The Southampton Women's Survey. Int J Epidemiol 35, $42-48$.

11. Segal M (2000) Picturing women's health. http://www. wellcome.ac.uk/en/magdasegal/index_no_fl.html (accessed February 2008)

12. Boyatzis RE (1998) Transforming Qualitative Information: Thematic Analysis and Code Development. London: Sage Publications.

13. Bove CF, Sobal J \& Rauschenbach BS (2003) Food choices among newly married couples: convergence, conflict, individualism, and projects. Appetite 40, 25-41.

14. Murcott A (1983) 'It's a pleasure to cook for him': food, mealtimes, and gender in some South Wales Households. In The Public and The Private, pp. 78-90. [E Garmarnikow, editor]. London: Heinemann.

15. Beagan BL \& Chapman GE (2004) Family influences on food choice: context of surviving breast cancer. J Nutr Educ Behav 36, 320-326.

16. Skinner EA (1996) A guide to constructs of control. J Pers Soc Psychol 71, 549-570.

17. Skinner EA (1998) Individual Differences and The Development of Perceived Control. Chicago, IL: University of Chicago Press.

18. Dibsdall LA, Lambert N \& Frewer LJ (2002) Using interpretative phenomenology to understand the foodrelated experiences and beliefs of a select group of lowincome UK women. J Nutr Educ Behav 34, 298-309.

19. Devine CM, Connors M, Bisogni CA \& Sobal J (1998) Lifecourse influences on fruit and vegetable trajectories: qualitative analysis of food choices. J Nutr Educ 30, 361-370. 